\title{
Title: Breakthrough SARS-CoV-2 Infections after Vaccination in North Carolina
}

Diane Uschner, $\mathrm{PhD}^{1}$, Matthew Bott, $\mathrm{BS}^{1}$, Michele Santacatterina, $\mathrm{PhD}^{1}$, Mihili Gunaratne, MPH, Lida M. Fette, MS ${ }^{1}$, Brian Burke, $\mathrm{MS}^{1}$, Greg Strylewicz, $\mathrm{PhD}^{1}$, Sharon L. Edelstein, $\mathrm{ScM}^{1}$, William H Lagarde, $\mathrm{MD}^{2}$, Kristen Miller, DrPH, CPPS ${ }^{3}$, William S. Weintraub, $\mathrm{MD}^{3}$, Joseph Keating, $\mathrm{PhD}^{4}$, John Schieffelin, $\mathrm{MD}^{4}$, Joshua Yukich, $\mathrm{PhD}^{4}$, Hazel Tapp, $\mathrm{PhD}^{5}$, Amina Ahmed, MD ${ }^{5}$, Andrea A. Berry, $\mathrm{MD}^{6}$, Iqra Munawar, $\mathrm{MS}^{7}$, Austin Lyles Seals, $\mathrm{MS}^{7}$, John Williamson, PharmD ${ }^{7}$, David Herrington, MD, $\mathrm{MHS}^{7}$, John W. Sanders, MD, MPH${ }^{7}$, Michael Runyon, MD, $\mathrm{MPH}^{5}$ for the COVID-19 Community Research Partnership **

Affiliations:

1 The Biostatistics Center, George Washington University, Rockville, Maryland

2 WakeMed Health and Hospitals, Raleigh, North Carolina

3 MedStar Health Research Institute and Georgetown University, Washington, District of Columbia

4 Tulane University, New Orleans, Louisiana

5 Atrium Health, Charlotte, North Carolina

6 University of Maryland School of Medicine

7 Wake Forest School of Medicine, Winston-Salem, North Carolina 
medRxiv preprint doi: https://doi.org/10.1101/2021.10.10.21264812; this version posted October 13, 2021. The copyright holder for this preprint (which was not certified by peer review) is the author/funder, who has granted medRxiv a license to display the preprint in perpetuity.

\section{It is made available under a CC-BY-NC-ND 4.0 International license .}

\section{Corresponding author:}

Dr. Diane Uschner

George Washington University

The Biostatistics Center

Rockville, MD

Email: duschner@bsc.gwu.edu

Text word count: 1199

Trial Registration: The COVID-19 Community Research Partnership is listed in clinicaltrials.gov (NCT04342884). 
medRxiv preprint doi: https://doi.org/10.1101/2021.10.10.21264812; this version posted October 13, 2021. The copyright holder for this preprint

(which was not certified by peer review) is the author/funder, who has granted medRxiv a license to display the preprint in perpetuity.

It is made available under a CC-BY-NC-ND 4.0 International license.

\section{Key Points}

Question: What are the characteristics of those with breakthrough infections after SARS-CoV-2 vaccination in North Carolina?

Findings: In this NC-based observational study of 16,020 participants, 1.9\% self-reported a positive SARS-CoV-2 viral test at least 2 weeks following full vaccination, reflecting an event rate of 7.3 infections per 100,000 person years. Rates were higher among younger participants, participants from more rural areas in North Carolina, and those vaccinated with J\&J Ad26.COV2.S.

Meaning: Our results show a relatively low rate of COVID-19 infection following full vaccination. Younger adults and those vaccinated with J\&J Ad26.COV2.S should be targeted for additional risk mitigation strategies.

Key Points word count: 100 (100 allowed) 


\begin{abstract}
Importance: Real-world data are needed to assess incidence and factors associated with breakthrough SARS-CoV-2 infections following vaccination.
\end{abstract}

Objective: Estimate incidence of breakthrough infections and assess associations with risk factors using self-reported data from a large NC population sample.

Design: Prospective observational cohort study utilizing daily online survey data to capture information about COVID-19 symptoms, testing, and vaccination status.

Setting: Six health care systems in North Carolina with data collected between January 15, 2021 and September 24, 2021.

Participants: Adult study participants who reported full vaccination with a COVID-19 mRNA or J\&J non-replicating viral vector vaccine $(n=16,020)$.

Exposures: Potential community exposure to SARS-CoV-2.

Main Outcome and Measures: Self-reported breakthrough infection.

Results: SARS-CoV-2 infection after vaccination was self-reported in $1.9 \%$ of participants, with an incidence rate of 7.3 per 100,000 person-years. Younger age $(45-64$ vs. $18-44$ : HR $(95 \% \mathrm{CI})=$ $0.65(0.51-0.82) ; 65+$ vs. $18-44:$ HR $(95 \% \mathrm{CI})=0.59(0.39-0.90))$, and vaccination with J\&J Ad26.COV2.S were associated with a higher risk of breakthrough infection compared to vaccination with Pfizer BNT162b2 (Ad26.COV2.S vs. BNT162b2: HR $(95 \%$ CI) $=2.23(1.40$ 3.56)), while participants vaccinated with mRNA-1273 (mRNA-1273 vs. BNT162b2: HR (95\% $\mathrm{CI})=0.69(0.50-0.96)$ and those residing in urban counties experienced a lower rate of SARSCoV-2 breakthrough infection compared with those from suburban $(\mathrm{HR}(95 \% \mathrm{CI})=1.39(1.01-$ $1.90)$ or rural $(\mathrm{HR}(95 \% \mathrm{CI})=1.57(1.16-2.11)$ counties. There was no significant association 
between breakthrough infection and participant sex, race, healthcare worker status, prior COVID-19 infection, routine mask use, or overall vaccination rate in the county of residence.

Conclusions and Relevance: This NC community-based observational study showed that the proportion of the cohort who self-report breakthrough SARS-CoV-2 infections was 7.3 events per 100,000 person-years. Younger adults, those vaccinated with J\&J Ad26.COV2.S, and those residing in suburban or rural counties were at higher risk of breakthrough infections and should be targeted for additional risk mitigation strategies to decrease community transmission.

\section{Abstract word count: 327}

Key words: COVID-19, breakthrough infection, vaccination 
Introduction Despite the remarkable clinical trial efficacy ${ }^{1-3}$ and real-world effectiveness of the SARS-CoV-2 vaccines, ${ }^{4}$ breakthrough infections do occur, potentially with significant clinical and public health consequences. ${ }^{5-7}$ While vaccine effectiveness appears to wane over time, ${ }^{8,9}$ studies of breakthrough infection have focused largely on subsequent healthcare utilization and clinical outcomes. ${ }^{10,11}$ Little is known about the risk factors associated with breakthrough infection such as age, race, sex, community exposure and behavior, and history of prior COVID19 infection. A better understanding of these factors may allow identification of a subset of vaccinated persons at higher risk of breakthrough infection for whom additional risk mitigation strategies may be needed. This investigation characterizes the overall incidence and risk factors associated with breakthrough infection among fully vaccinated participants in the North Carolina (NC) COVID-19 Community Research Partnership (CRP).

\section{Methods}

The NC CRP is a prospective, observational cohort study that solicited participants for COVID19 symptoms, test results, vaccination status and risk behavior via daily email or text surveys. Adults 18 years and older were enrolled between April 13, 2020 and August 14, 2021 at six NC healthcare systems (http://www.covid19communitystudy.org/). This study was approved by the Wake Forest School of Medicine Institutional Review Board. Participants consented to allow access to their electronic health records (EHR). Demographic data and healthcare worker status were collected at enrollment. Counties of residence were classified as urban, suburban or rural based on population density estimates. ${ }^{12}$ Symptoms of COVID-19 included fever, chills, cough, shortness of breath, fatigue, muscle pain, headache, loss of taste/smell, sore throat, congestion/runny nose, nausea/vomiting, and diarrhea. We defined SARS-CoV-2 vaccination as participant self-report of receiving two doses of either the Pfizer BioNTech BNT162b2 or 
Moderna mRNA-1273 vaccine, or one dose of the Janssen (Johnson \& Johnson, J\&J) nonreplicating viral vector vaccine Ad26.COV2.S. Vaccination status was confirmed for the subset of participants with accessible EHR data. The primary outcome was weeks until first selfreported infection (positive SARS-CoV-2 antigen or nucleic acid amplification test) occurring $\geq$ 14 days after vaccination (between January 15, 2021 and September 24, 2021). The secondary outcome was time to symptomatic infection defined as one or more self-reported symptom suggestive of COVID-19 \pm 3 days from the date of a positive test. General mask usage as a proxy for COVID-19 risk mitigation behavior was defined as wearing a face mask $90 \%$ or more of the time when meeting people outside the household in the 14 days after vaccination.

Statistical methods Descriptive statistics are presented as absolute and relative frequencies for categorical variables and median and inter-quartile range (IQR) for follow-up time. Cumulative incidence was estimated as 1 minus the Kaplan-Meier curve. Unadjusted cumulative event rates were estimated as number of events by person time. Cox proportional hazards models were used to estimate unadjusted and adjusted hazard ratios with $95 \%$ confidence intervals (CI). Only main effects were considered in the analysis. Three participants who did not specify their sex at enrollment were excluded from analysis. There were no other missing data. All variables of interest were selected a-priori and were used as covariates in the multivariable model. Exploratory data analysis highlighted the large effect of vaccination quarter, likely related to the non-uniform effect of calendar time on risk for breakthrough due to the delta SARS-CoV-2 variant (eFigure 1). Accordingly, univariate and multivariate analyses were adjusted for vaccination quarter before estimating HRs for breakthrough infection after vaccination. Analyses were performed using R (V.4.0.3, R Foundation for Statistical Computing). 
medRxiv preprint doi: https://doi.org/10.1101/2021.10.10.21264812; this version posted October 13, 2021. The copyright holder for this preprint (which was not certified by peer review) is the author/funder, who has granted medRxiv a license to display the preprint in perpetuity.

It is made available under a CC-BY-NC-ND 4.0 International license .

Results Of 16,020 eligible participants, 310 (1.9\%) reported a positive SARS-CoV-2 test after vaccination (eFigure 2). The event rate was 7.3 breakthrough infections per 100,000 personyears. Infections were symptomatic in $286(92 \%)$ cases. Population characteristics are summarized in Table 1. Median and interquartile follow-up times following full vaccination were 24.0, IQR $=(17-28.4)$ weeks among infected participants and 23.6, IQR $=(17.4-29.9)$ weeks among uninfected participants. The cumulative incidence of breakthrough infection was $5.2 \%$ at 34 weeks following full vaccination (Figure 1). In the multivariable analysis (Table 1), age 45 and older was associated with lower risk of breakthrough infection; HR (95\% CI) of age 45-64 vs. $18-44$ was 0.65 (0.51 - 0.82); age $65+$ vs. $18-44$ was $0.59(0.39-0.90)$. Compared to those vaccinated with BNT162b2, participants vaccinated with Ad26.COV2.S had a higher risk of breakthrough infection; HR $(95 \% \mathrm{CI})=2.23(1.40$ - 3.56) and those vaccinated with mRNA1273 had a lower risk of breakthrough infection; HR $(95 \% \mathrm{CI})=0.69(0.50-0.96)$. Participants from rural and suburban counties had a higher risk of breakthrough infections; HR (95\% CI) of suburban vs. urban was $1.39(1.01-1.90)$; rural vs. urban was $1.57(1.16-2.11)$. There was no association of breakthrough infection with sex, race/ethnicity, healthcare worker status, prior self-reported COVID-19 infection, general mask usage, or vaccination rate in the county of residence.

\section{Discussion}

In this community-based observational study, the cumulative incidence of participants in North Carolina who self-reported SARS-CoV-2 infection was $5.2 \%$ by 34 weeks following full vaccination. The study period included a statewide surge in cases driven by the Delta variant, with a comparable number of new cases as during the winter of 2020-21. The overall breakthrough infection event rate was 7.3 events per 100,000 person-years. Participants 
vaccinated with Ad26.COV2.S, participants younger than 45 years, and those from rural and suburban counties were at higher risk of breakthrough infection. The association with younger age may reflect more frequent exposures, higher risk exposures, age-associated differences in mitigation behaviors, or a combination of these factors. The association with rural residence may reflect increased transmission in areas with generally lower rates of vaccination ${ }^{13-15}$ though we did not find a significant difference in breakthrough infection rates when comparing counties with a high $(\geq 60 \%)$ vs low $(<60 \%)$ overall vaccination rate. Race/ethnicity, sex, and occupation as healthcare workers were not associated with higher risk for infection after vaccination. The analysis did not detect a difference in breakthrough infection rates based on general mask usage as a proxy for COVID-19 risk mitigation behavior. However, the conclusions from general mask usage is limited because it is not linked to a specific exposure.

These findings may be limited by selection and reporting biases and may not be generalizable to other areas of the country. Participants were largely recruited through their affiliated healthcare system or EHR (e.g. through electronic patient portal systems); therefore, they may be more engaged in healthcare than the general population. This study includes self-report of a new positive test for COVID-19, generally accompanied by symptoms, so paucisymptomatic or asymptomatic infections may be missed. The results are dependent on transmission rates within the community, which will vary during the course of the pandemic.

In conclusion, this large NC based observational study conducted in a real-world setting demonstrated an event rate of 7.3 breakthrough infections per 100,000 person-years. Breakthrough infection occurred at a higher rate in rural parts of North Carolina, among the 
younger population and those vaccinated with Ad26.COV2.S. While the underlying causes of the observed differences in breakthrough infection rates deserve further study, our findings suggest that younger adults, those who received the Ad26.COV2.S vaccination, and those residing in suburban and rural counties should be targeted for additional risk mitigation strategies to prevent infection and further transmission of SARS-CoV-2.

\section{Acknowledgements}

The COVID-19 Community Research Partnership gratefully acknowledges the commitment and dedication of the study participants. Programmatic, laboratory, and technical support was provided by Vysnova Partners, Inc., Javara, Inc., and Oracle Corporation.

Funding/Support: This publication was supported by the CARES Act of the U.S. Department of Health and Human Services (HHS) [Contract \# NC DHHS GTS \#49927]. The Partnership is listed in clinicaltrials.gov (NCT04342884).

Role of the Funder/Sponsor: The CARES Act of the U.S. of the HHS had no role.

Conflicts of Interest: All authors declare that they have no competing interests 


\section{Author Contributions}

Dr. Uschner and Mr. Bott had full access to all of the data in the study and take responsibility for the integrity of the data and the accuracy of the data analysis.

Concept and design: Uschner, Santacatterina Herrington, Runyon

Acquisition, analysis, or interpretation of data: All authors

Drafting of the manuscript: Uschner, Runyon

Critical revision of the manuscript for important intellectual content: All authors

Statistical analysis: Uschner, Bott, Munawar, Seals

Obtained funding: Herrington, Sanders, Uschner

Administrative, technical, or material support: Uschner, Bott, Fette, Gunaratne, Burke

Supervision: Uschner, Santacatterina, Herrington, Sanders, Runyon

\section{**The COVID-19 Community Research Partnership}

Wake Forest School of Medicine: John Walton Sanders*, MD, MPH, Thomas F Wierzba*,

PhD, MPH, David Herrington*, MD, MHS, Mark A. Espeland, PhD, Morgana Mongraw-

Chaffin, PhD, Alain Bertoni, MD, Martha A. Alexander-Miller, PhD, Allison Mathews, PhD,

Iqra Munawar, MS, Austin Lyles Seals, MS, Brian Ostasiewski, Christine Ann Pittman Ballard, MPH, Metin Gurcan, PhD, Alexander Ivanov, MD, Allison Matthews, PhD, Giselle Melendez

Zapata, MD, Marlena Westcott, PhD, Karen Blinson, Laura Blinson, Douglas McGlasson, Mark

Mistysyn, Donna Davis, Lynda Doomy, Perrin Henderson, MS, Alicia Jessup, Kimberly Lane,

Beverly Levine, PhD, Jessica McCanless, MS, Sharon McDaniel, Kathryn Melius, MS, Christine 
O’Neill, Angelina Pack, RN, Ritu Rathee, RN, Scott Rushing, Jennifer Sheets, Sandra Soots, RN, Michele Wall, Samantha Wheeler, John White, Lisa Wilkerson, Rebekah Wilson, Kenneth Wilson, Deb Burcombe, John Williamson, PharmD

Atrium Health: Michael S. Runyon*, MD MPH, Lewis H. McCurdy*, MD, Michael A. Gibbs, MD, Yhenneko J. Taylor, PhD, Lydia Calamari, MD, Hazel Tapp, PhD, Amina Ahmed, MD, Michael Brennan, DDS, Lindsay Munn, PhD RN, Keerti L. Dantuluri, MD, Timothy Hetherington, MS, Lauren C. Lu, Connell Dunn, Melanie Hogg, MS, CCRA, Andrea Price, Marina Leonidas, Laura Staton, Kenniesha Spencer, MPH, Melinda Manning, Whitney Rossman, MS, Frank X. Gohs, MS, Anna Harris, MPH, Bella Gutnik MS, Jennifer S. Priem, PhD, MA, Ryan Burns, MS

MedStar Health Research Institute: William Weintraub*, MD , Kristen Miller, DrPH, CPPS, , Chris Washington, Allison Moses, Sarahfaye Dolman, Julissa Zelaya-Portillo, John Erkus, Joseph Blumenthal, Ronald E. Romero Barrientos, Sonita Bennett, Shrenik Shah, Shrey Mathur, Christian Boxley, Paul Kolm, PhD, Eva Hochberger, Ella Franklin, Deliya Wesley, Naheed Ahmed

Tulane: Richard Oberhelman*, MD, Joseph Keating*, PhD, Patricia Kissinger, PhD, John Schieffelin, MD, Joshua Yukich, PhD, Andrew “AJ” Beron, MPH, Devin Hayes, BS, Johanna Teigen, MPH

University of Maryland School of Medicine: Karen Kotloff*, MD, Wilbur H. Chen*, MD, MS, DeAnna Friedman-Klabanoff, MD, Andrea A. Berry, MD, Helen Powell, PhD, Lynnee Roane, MS, RN, Reva Datar, MPH 
University of Mississippi: Adolfo Correa*, MD, PhD, Leandro Mena*, MD, MPH, Bhagyashri

Navalkele, MD, Yuan-I Min, PhD, Alexandra Castillo, MPH, Lori Ward, PhD, MS, Robert P.

Santos, MD, Courtney Gomillia, MS-PHS, Pramod Anugu, Yan Gao, MPH, Jason Green,

Ramona Sandlin, RHIA, Donald Moore, MS, Lemichal Drake, Dorothy Horton, RN, Kendra L.

Johnson, MPH

Wake Med Health and Hospitals: William H. Lagarde*, MD, LaMonica Daniel, BSCR

New Hanover: Patrick D. Maguire*, MD, Charin L. Hanlon, MD, Lynette McFayden, RN, Isaura Rigo, MD, Kelli Hines, Lindsay Smith, Alexa Drilling, Monique Harris, Belinda Lissor, Vivian Cook, Maddy Eversole, Terry Herrin, Dennis Murphy, Lauren Kinney, Polly Diehl, Nicholas Abromitis, Tina St. Pierre, Judy Kennedy BSCS, MBA, Lauren Kinney, BS, Bill Heckman, Denise Evans, Vivian Cook, Maddy Eversole, Julian March, Ben Whitlock, Wendy Moore

Vidant Health: Thomas R. Gallaher*, MD, Shakira Henderson, PhD, DNP, MS, MPH, Michael Zimmer, PhD, Danielle Oliver, Tina Dixon, Kasheta Jackson, Martha Reavis, Monica Menon, Brandon Bishop, Rachel Roeth, Mathew Johanson, Alesia Ceaser, Amada Fernandez, Carmen Williams, Jeremiah Hargett, Keeaira Boyd, Kevonna Forbes, Latasha Thomas, Markee Jenkins, Monica Coward, Derrick Clark, Omeshia Frost, Angela Darden, Lakeya Askew, Sarah Phipps, Victoria Barnes

Campbell University School of Osteopathic Medicine: Robin King-Thiele*, DO, Terri S. Hamrick*, PhD, Chika Okafor, MD (Cape Fear Valley Medical Center), Regina B. Bray Brown, MD (Harnett Health System, Inc.), Pinoorma Vinod, MD (Southeastern Health), Lawrence Klima, MD (Harnett Health System), Amber Brewster, MD (Harnett Health System), Danius Bouyi, DO (Harnett Health System), Katrina Lamont, MD (Harnett Health System), Kazumi 
Yoshinaga, DO (Harnett Health System), Abdalla Ihmeidan, MHA (Campbell University School of Osteopathic Medicine), A. Suman Peela, MD (Southeastern Health System), Giera Denbel, MD (Southeastern Health System), Jason Lo, MD: Southeastern Health System, Mariam MayetKhan, DO (Southeastern Health System), Akash Mittal, DO (Southeastern Health System), Reena Motwani, MD (Southeastern Health System), Mohamed Raafat, MD (Southeastern Health System), Evan Schultz, DO (Cumberland County Hospital System, Cape Fear Valley), Aderson Joseph, MD (Cumberland County Hospital System, Cape Fear Valley), Aalok Parkeh, DO (Cumberland County Hospital System, Cape Fear Valley), Dhara Patel, MD (Cumberland County Hospital System, Cape Fear Valley), Babar Afridi, DO (Cumberland County Hospital System, Cape Fear Valley)

George Washington University Data Coordinating Center: Diane Uschner*, PhD, Sharon L Edelstein, ScM, Michele Santacatterina, PhD, Greg Strylewicz, PhD, Brian Burke, MS, Mihili Gunaratne, MPH, Meghan Turney, MA, Shirley Qin Zhou, MS, Ashley H Tjaden, MPH, Lida Fette, MS, Asare Buahin, Matthew Bott, Sophia Graziani, Ashvi Soni, MS

George Washington University Mores Lab: Christopher Mores, PhD, Abigail Porzucek, MS

Oracle Corporation: Rebecca Laborde

Vysnova Partners: Anne McKeague, PhD, Grace Tran, MPH, Johnathan Ward, Joyce Dieterly, MPH, Nana Darko, MPH, Kimberly Castellon, Isabella Malcolm, Ryan Brink, MS, Haris

Shehzad, MS, Derek Kuprianov

Sneez LLC: Lucy Guill, MBA, Danielle Lamphier, MBA, Anna Schaefer, MSM, William M. Satterwhite, JD, MD

Javara Inc: Atira Goodwin 
medRxiv preprint doi: https://doi.org/10.1101/2021.10.10.21264812; this version posted October 13, 2021. The copyright holder for this preprint (which was not certified by peer review) is the author/funder, who has granted medRxiv a license to display the preprint in perpetuity. It is made available under a CC-BY-NC-ND 4.0 International license .

External Advisory Council: Ruth Berkelman, MD, Emory, Kimberly Hanson, MD, U of Utah, Scott Zeger, PhD, Johns Hopkins, Cavan Reilly, PhD, U. of Minnesota, Kathy Edwards, MD, Vanderbilt, Helene Gayle, MD MPH, Chicago Community Trust

(*Site Principal Investigator) 
medRxiv preprint doi: https://doi.org/10.1101/2021.10.10.21264812; this version posted October 13, 2021. The copyright holder for this preprint (which was not certified by peer review) is the author/funder, who has granted medRxiv a license to display the preprint in perpetuity.

It is made available under a CC-BY-NC-ND 4.0 International license .

\section{References}

1. Baden LR, El Sahly HM, Essink B, et al. Efficacy and Safety of the mRNA-1273 SARS-CoV-2 Vaccine. New England Journal of Medicine 2020;384:403-16.

2. Polack FP, Thomas SJ, Kitchin N, et al. Safety and Efficacy of the BNT162b2 mRNA Covid19 Vaccine. New England Journal of Medicine 2020;383:2603-15.

3. Sadoff J, Gray G, Vandebosch A, et al. Safety and Efficacy of Single-Dose Ad26.COV2.S Vaccine against Covid-19. New England Journal of Medicine 2021;384:2187-201.

4. Thompson MG, Burgess JL, Naleway AL, et al. Prevention and Attenuation of Covid-19 with the BNT162b2 and mRNA-1273 Vaccines. New England Journal of Medicine 2021;385:320-

9.

5. Haas EJ, Angulo FJ, McLaughlin JM, et al. Impact and effectiveness of mRNA BNT162b2 vaccine against SARS-CoV-2 infections and COVID-19 cases, hospitalisations, and deaths following a nationwide vaccination campaign in Israel: an observational study using national surveillance data. Lancet 2021;397:1819-29.

6. Harris RJ, Hall JA, Zaidi A, Andrews NJ, Dunbar JK, Dabrera G. Effect of Vaccination on Household Transmission of SARS-CoV-2 in England. New England Journal of Medicine 2021;385:759-60.

7. M S, JW S, WS W, C-CR Pf. Real World SARS-CoV2 Vaccine Effectiveness: The North Carolina COVID-19 Community Research Partnership. New England Journal of Medicine 2021. 8. Fowlkes A, Gaglani M, Groover K, Thiese MS, Tyner H, Ellingson K. Effectiveness of COVID-19 Vaccines in Preventing SARS-CoV-2 Infection Among Frontline Workers Before and During B.1.617.2 (Delta) Variant Predominance - Eight U.S. Locations, December 2020-August 2021. MMWR Morb Mortal Wkly Rep 2021;70:1167-9.

9. Pegu A, O'Connell SE, Schmidt SD, et al. Durability of mRNA-1273 vaccine-induced antibodies against SARS-CoV-2 variants. Science 2021;373:1372-7.

10. Bahl A, Johnson S, Maine $G$, et al. Vaccination reduces need for emergency care in breakthrough COVID-19 infections: A multicenter cohort study. Lancet Reg Health Am 2021:100065.

11. Butt AA, Nafady-Hego $\mathrm{H}$, Chemaitelly $\mathrm{H}$, et al. Outcomes Among Patients with Breakthrough SARS-CoV-2 Infection After Vaccination. Int J Infect Dis 2021;110:353-8.

12. NC Rural Center/About Us. 2021. at https://www.ncruralcenter.org/about-us/.) 13. COVID-19 North Carolina Dashboard. 2021. at https://covid19.ncdhhs.gov/dashboard.) 14. COVID Vaccinations are Climbing, Slowly, in Rural North Carolina. But Skepticism Remains. 2021. at https://www.northcarolinahealthnews.org/2021/08/14/covid-vaccinationsare-climbing-slowly-in-rural-north-carolina-but-skepticism-remains/.)

15. Rural North Carolina hospital leader emerges as outspoken critic of COVID 'noise'. 2021. at https://www.northcarolinahealthnews.org/2021/09/12/rural-north-carolina-hospital-leaderemerges-as-outspoken-critic-of-covid-noise/.) 


\section{Figure 1.}

Title: Cumulative Incidence of Self-reported Symptomatic SARS-CoV-2 Test

Caption: Cumulative incidence curves (1 minus the unadjusted Kaplan-Meier risk), number at risk and the cumulative number of events at each time point for the first self-reported symptomatic positive SARS-CoV-2 test, starting from 2 weeks after the last dose among participants who reported full vaccination.

A

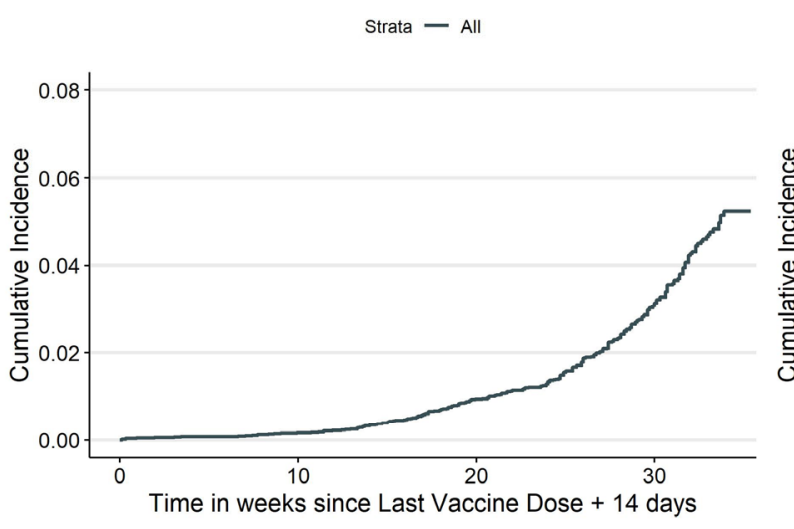

No. at Risk

All 16020

13507

11161

3905

C

Strata - Rural - Suburban - Urban

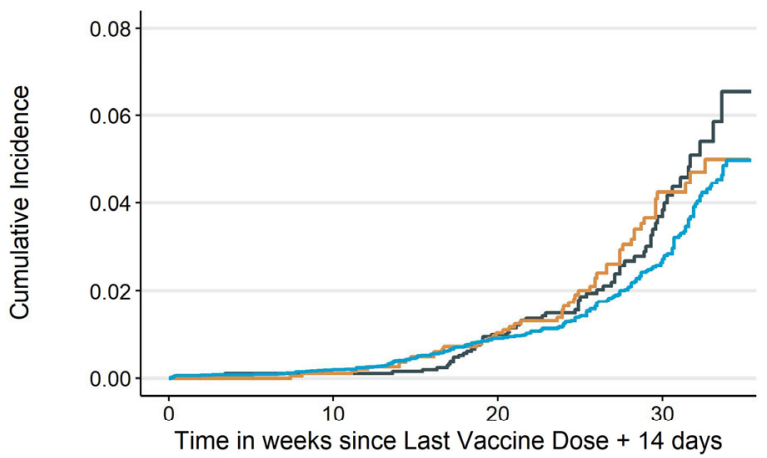

No. at Risk
B

Strata - Ad26.COV2.S - mRNA-1273 - BNT162b2

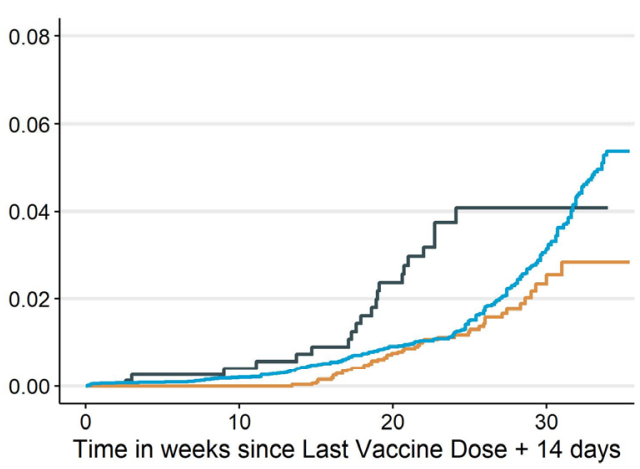

No. at Risk

\begin{tabular}{|c|c|c|c|}
\hline Ad26.COV2.S 824 & 653 & 511 & 1 \\
\hline mRNA-1273 3997 & 3399 & 2818 & 468 \\
\hline BNT162b2 11199 & 9455 & 7832 & 436 \\
\hline
\end{tabular}

D

Strata - 18-44 - 45-64 $-65+$

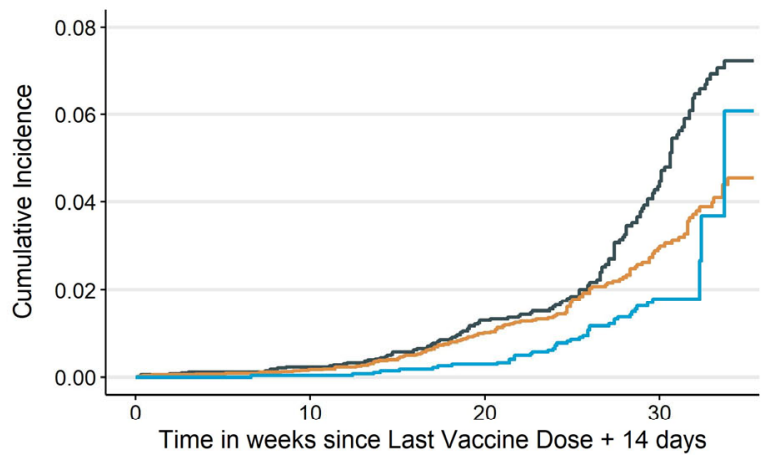

No. at Risk

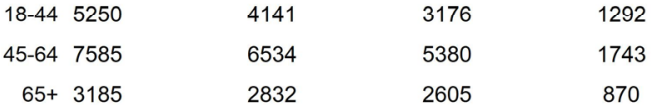


Table 1. SARS-CoV-2 Infection rate after vaccination per 100,000 person-years overall and by risk factors

\begin{tabular}{|c|c|c|c|c|c|c|c|}
\hline \multirow[b]{2}{*}{ Characteristics } & \multirow[b]{2}{*}{$\mathbf{N}(\%)$} & \multirow[b]{2}{*}{$\begin{array}{c}\text { \# Of Events } \\
\text { (\%) }\end{array}$} & \multirow[b]{2}{*}{$\begin{array}{c}\text { Event Rate } \\
(95 \% \mathrm{Cl})\end{array}$} & \multicolumn{2}{|c|}{ Univariate $^{a}$} & \multicolumn{2}{|c|}{ Multivariate $^{\mathrm{b}}$} \\
\hline & & & & $\begin{array}{l}\text { Hazard Ratio } \\
(95 \% \mathrm{Cl})\end{array}$ & P-value & $\begin{array}{l}\text { Hazard Ratio } \\
\qquad(95 \% \mathrm{Cl})\end{array}$ & P-value \\
\hline \multicolumn{8}{|l|}{ Age } \\
\hline 18-44 (Reference group) & $5250(33 \%)$ & $133(2.5 \%)$ & $10.3(8.7-12.2)$ & & & & \\
\hline $45-64$ & $7585(47 \%)$ & $135(1.8 \%)$ & $6.7(5.7-8)$ & $0.64(0.5-0.81)$ & 0.0003 & $0.65(0.51-0.82)$ & 0.0004 \\
\hline $65+$ & $3185(20 \%)$ & $42(1.3 \%)$ & $4.4(3.3-6)$ & $0.49(0.34-0.7)$ & 0.0001 & $0.59(0.39-0.89)$ & 0.0129 \\
\hline \multicolumn{8}{|l|}{ Sex } \\
\hline Female (Reference group) & $11794(74 \%)$ & $230(2 \%)$ & $7.3(6.4-8.3)$ & & & & \\
\hline Male & $4226(26 \%)$ & $80(1.9 \%)$ & $7.2(5.8-8.9)$ & $1.01(0.78-1.3)$ & 0.9452 & $1.14(0.88-1.48)$ & 0.3130 \\
\hline \multicolumn{8}{|l|}{ Race/Ethnicity } \\
\hline Non-Hispanic White (Reference group) & $15054(94 \%)$ & $294(2 \%)$ & $7.3(6.5-8.2)$ & & & & \\
\hline Non-Hispanic Black & $401(3 \%)$ & $3(0.7 \%)$ & $3.2(1-9.9)$ & $0.5(0.16-1.55)$ & 0.2300 & $0.44(0.14-1.38)$ & 0.1613 \\
\hline Hispanic & $172(1 \%)$ & $5(2.9 \%)$ & $12.9(5.4-31)$ & $1.85(0.76-4.47)$ & 0.1746 & $1.52(0.62-3.69)$ & 0.3580 \\
\hline Non-Hispanic Other & $393(2 \%)$ & $8(2 \%)$ & $8.5(4.2-16.9)$ & $1.2(0.59-2.42)$ & 0.6100 & $1.03(0.51-2.1)$ & 0.9307 \\
\hline \multicolumn{8}{|l|}{ Healthcare Worker Status } \\
\hline No (Reference group) & $10559(66 \%)$ & $158(1.5 \%)$ & $5.9(5.1-6.9)$ & & & & \\
\hline Yes & $5461(34 \%)$ & $152(2.8 \%)$ & $9.6(8.2-11.3)$ & $1.53(1.16-2.02)$ & 0.0029 & $1.33(0.95-1.85)$ & 0.0965 \\
\hline \multicolumn{8}{|l|}{ Vaccination Brand } \\
\hline Pfizer BNT162b2 (Reference group) & $11199(70 \%)$ & $242(2.2 \%)$ & $7.9(7-9)$ & & & & \\
\hline Moderna mRNA-1273 & $3997(25 \%)$ & $47(1.2 \%)$ & $4.6(3.5-6.2)$ & $0.68(0.5-0.94)$ & 0.0187 & $0.69(0.5-0.96)$ & 0.0281 \\
\hline Janssen (Johnson \& Johnson) Ad26.COV2.S & $824(5 \%)$ & $21(2.5 \%)$ & $11.4(7.5-17.5)$ & $2.13(1.34-3.37)$ & 0.0013 & $2.23(1.4-3.56)$ & 0.0007 \\
\hline \multicolumn{8}{|l|}{ Prior COVID Infection } \\
\hline No (Reference group) & $15359(96 \%)$ & $298(1.9 \%)$ & $7.3(6.5-8.2)$ & & & & \\
\hline Yes & $661(4 \%)$ & $12(1.8 \%)$ & $7.4(4.2-13)$ & $1.03(0.58-1.83)$ & 0.9323 & $0.94(0.53-1.68)$ & 0.8382 \\
\hline \multicolumn{8}{|l|}{ Vaccination Rate in County of Residence } \\
\hline$<60 \%$ (Reference group) & 13617 (85\%) & $258(1.9 \%)$ & $7.1(6.3-8)$ & & & & \\
\hline$\geq 60 \%$ & $2403(15 \%)$ & $52(2.2 \%)$ & $8.3(6.3-10.9)$ & $1.2(0.89-1.61)$ & 0.2404 & $1.31(0.95-1.79)$ & 0.0966 \\
\hline \multicolumn{8}{|l|}{ County Classification } \\
\hline Urban (Reference group) & $10729(67 \%)$ & 195 (1.8\%) & $6.8(5.9-7.8)$ & & & & \\
\hline Suburban & $2366(15 \%)$ & $52(2.2 \%)$ & $8.5(6.4-11.1)$ & $1.25(0.92-1.7)$ & 0.1539 & $1.39(1.01$ - 1.9) & 0.0407 \\
\hline Rural & 2925 (18\%) & $63(2.2 \%)$ & $8.2(6.4-10.6)$ & 1.27 (0.96 - 1.69) & 0.0942 & $1.57(1.16-2.11)$ & 0.0033 \\
\hline \multicolumn{8}{|l|}{ Mask Usage $^{c}$} \\
\hline$\leq 90 \%$ (Reference group) & $10186(64 \%)$ & $198(1.9 \%)$ & $7.4(6.4-8.5)$ & & & & \\
\hline$>90 \%$ & $5834(36 \%)$ & $112(1.9 \%)$ & $7.1(5.9-8.6)$ & $0.91(0.72-1.15)$ & 0.4165 & $0.87(0.68-1.1)$ & 0.2348 \\
\hline Total Number of Participants & $16020(100 \%)$ & $310(1.9 \%)$ & $7.3(6.5-8.1)$ & & & & \\
\hline
\end{tabular}

a Hazard ratios for individual variables after adjusting for vaccine quarter (e.g. Jan-Mar, Apr-Jun, Jul-Sept)

${ }^{\mathrm{b}}$ Includes all variables in this table and is adjusted for vaccine quarter (e.g. Jan-Mar, Apr-Jun, Jul-Sept)

${ }^{\mathrm{c}}$ Mask usage in the 2 weeks following vaccination as a proxy for general COVID-19 risk mitigation behavior 


\section{Online-Only Figures - eFigure 1}

Title: SARS-CoV-2 Infections after vaccination and calendar time

Caption: Distribution of SARS-CoV-2 infections after vaccinations by time (LHS) and cumulative incidence by quarter of vaccination date (RHS, Q1 = Vaccination in January-March 2021, Q2 = Vaccination in April-June 2021, Q3 = Vaccination in July-September 2021)

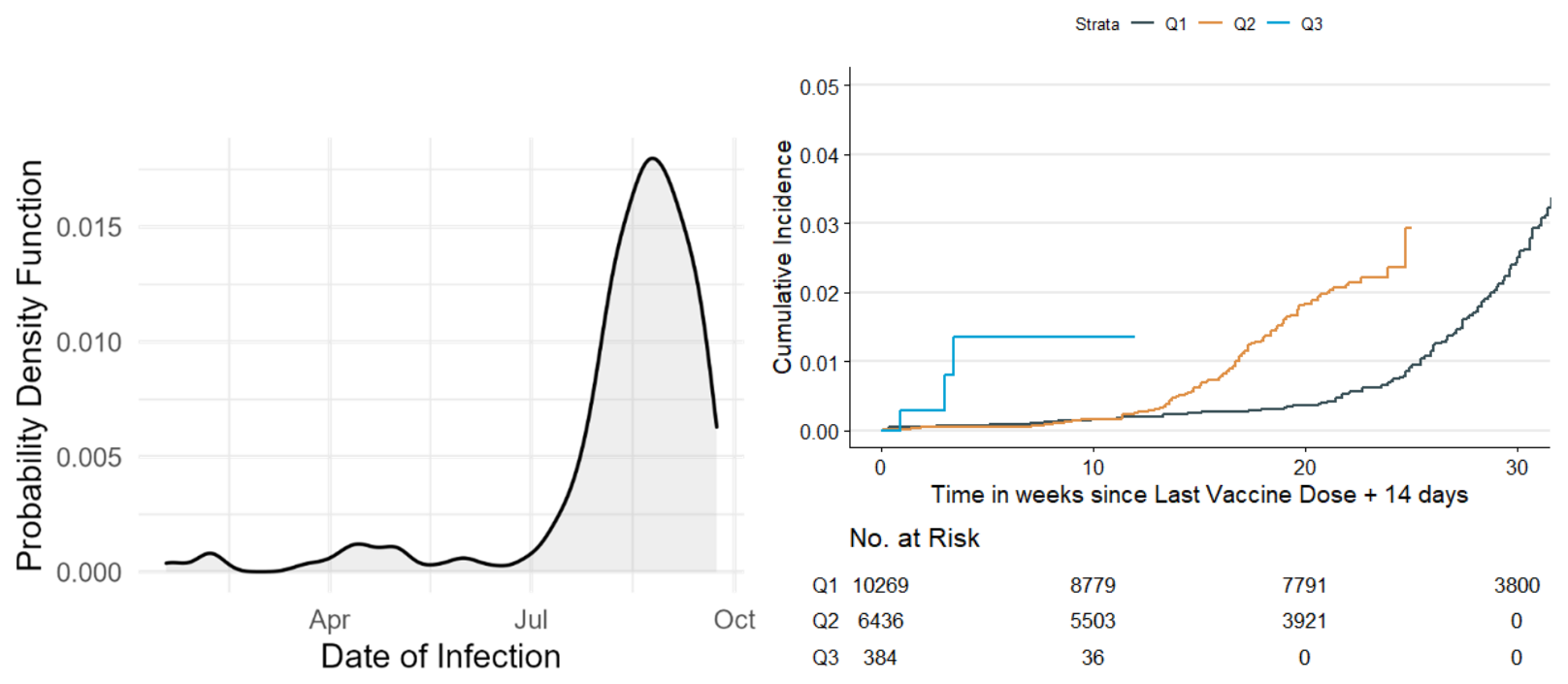


medRxiv preprint doi: https://doi.org/10.1101/2021.10.10.21264812; this version posted October 13, 2021. The copyright holder for this preprint (which was not certified by peer review) is the author/funder, who has granted medRxiv a license to display the preprint in perpetuity.

\section{It is made available under a CC-BY-NC-ND 4.0 International license .}

\section{Online-Only Figures - eFigure 2}

Title: Flow diagram describing the study population

\section{Caption: NA}

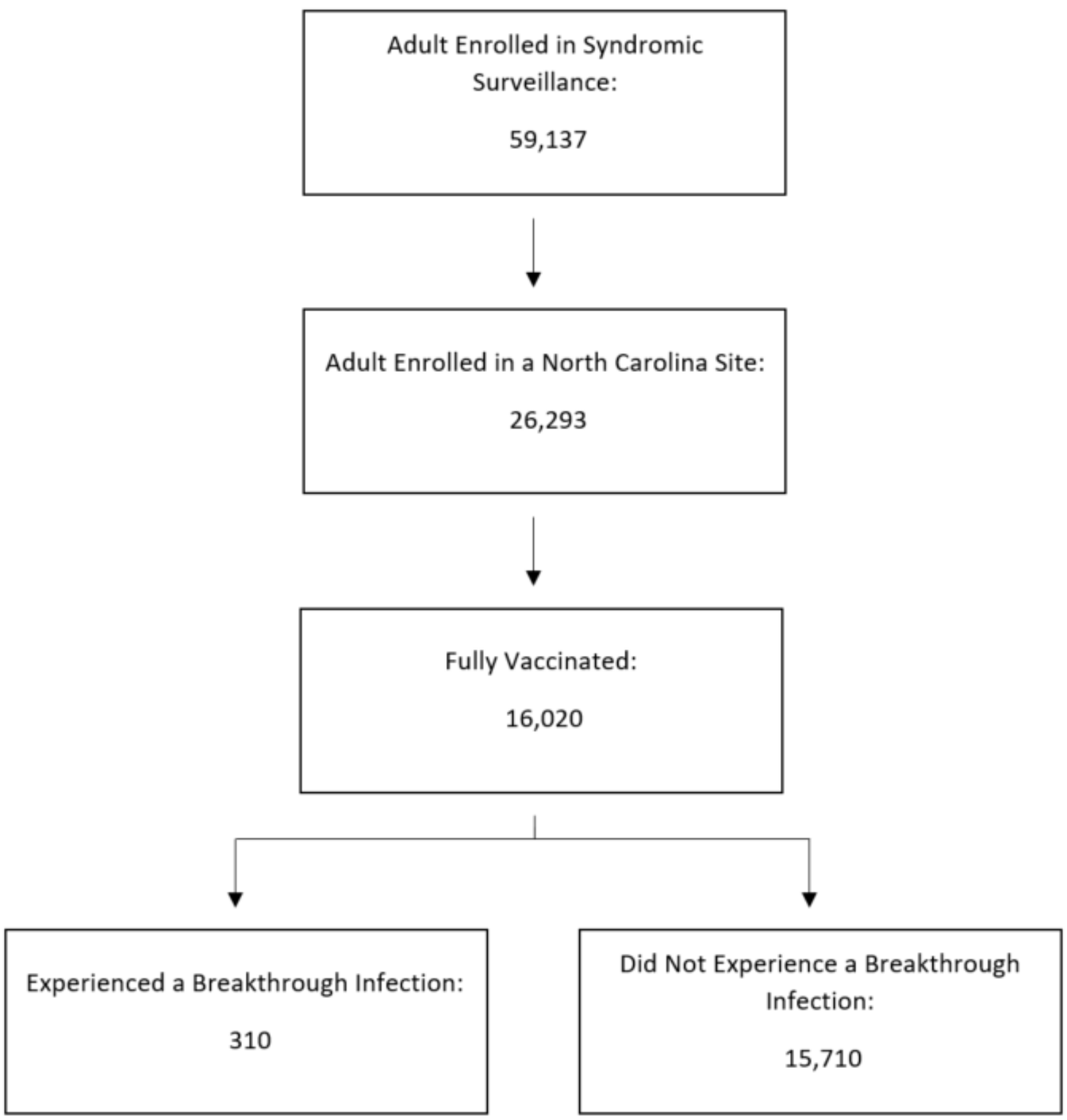




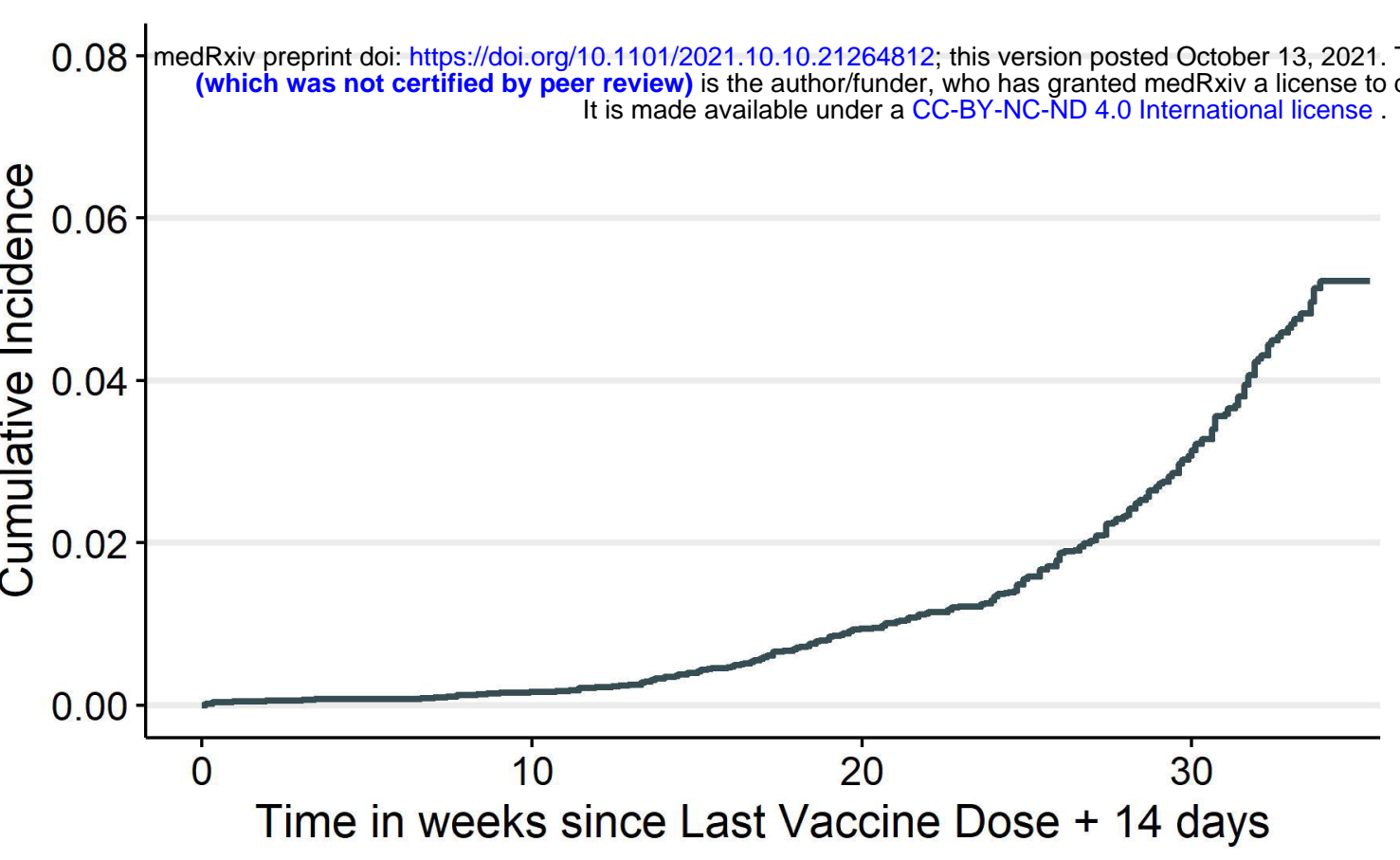

No. at Risk

All 16020

13507

11161

3905

C

Strata - Rural - Suburban - Urban

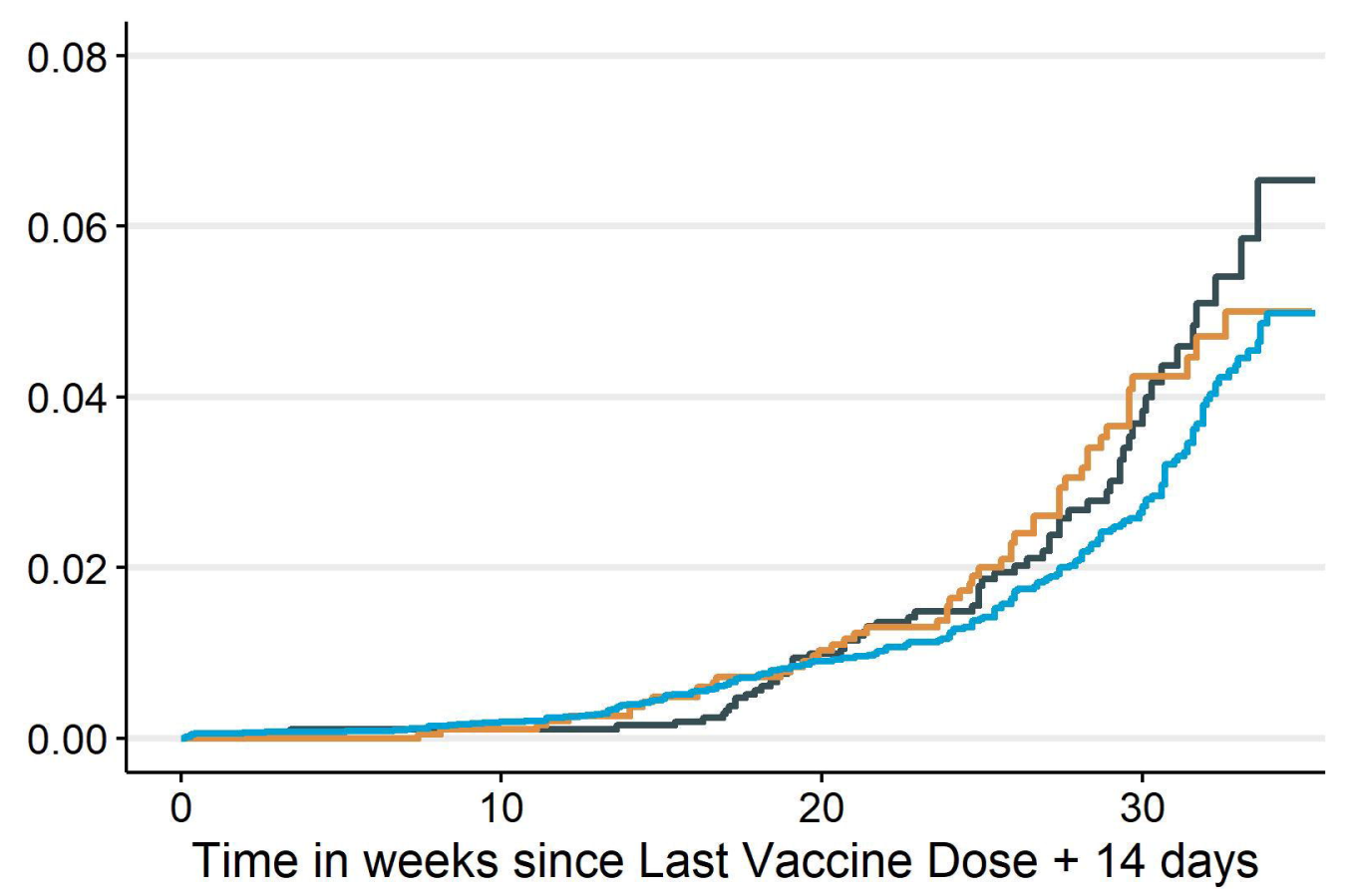

No. at Risk

Rural 2924

2444

2002

1935

1546

639

Suburban 2365

9128

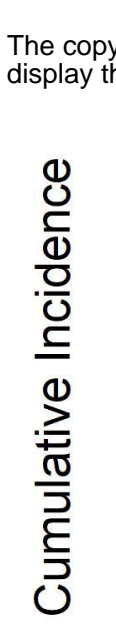

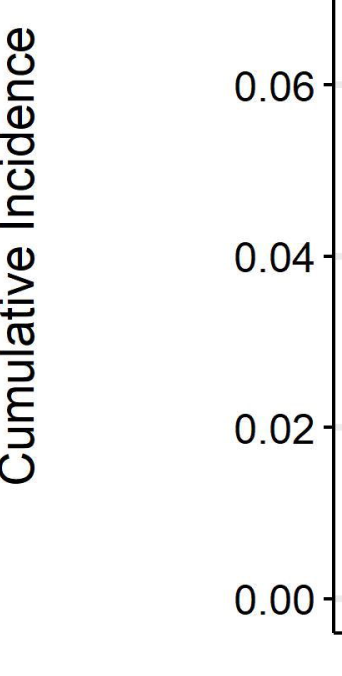

in perpety ity.

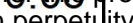

0

Time in weeks since Last Vaccine Dose +14 days

No. at Risk

\begin{tabular}{|c|c|c|}
\hline Ad26.COV2.S 824 & 653 & 511 \\
\hline mRNA-1273 3997 & 3399 & 2818 \\
\hline BNT162b2 11199 & 9455 & 7832 \\
\hline
\end{tabular}

D

Strata $-18-44=45-64-65+$

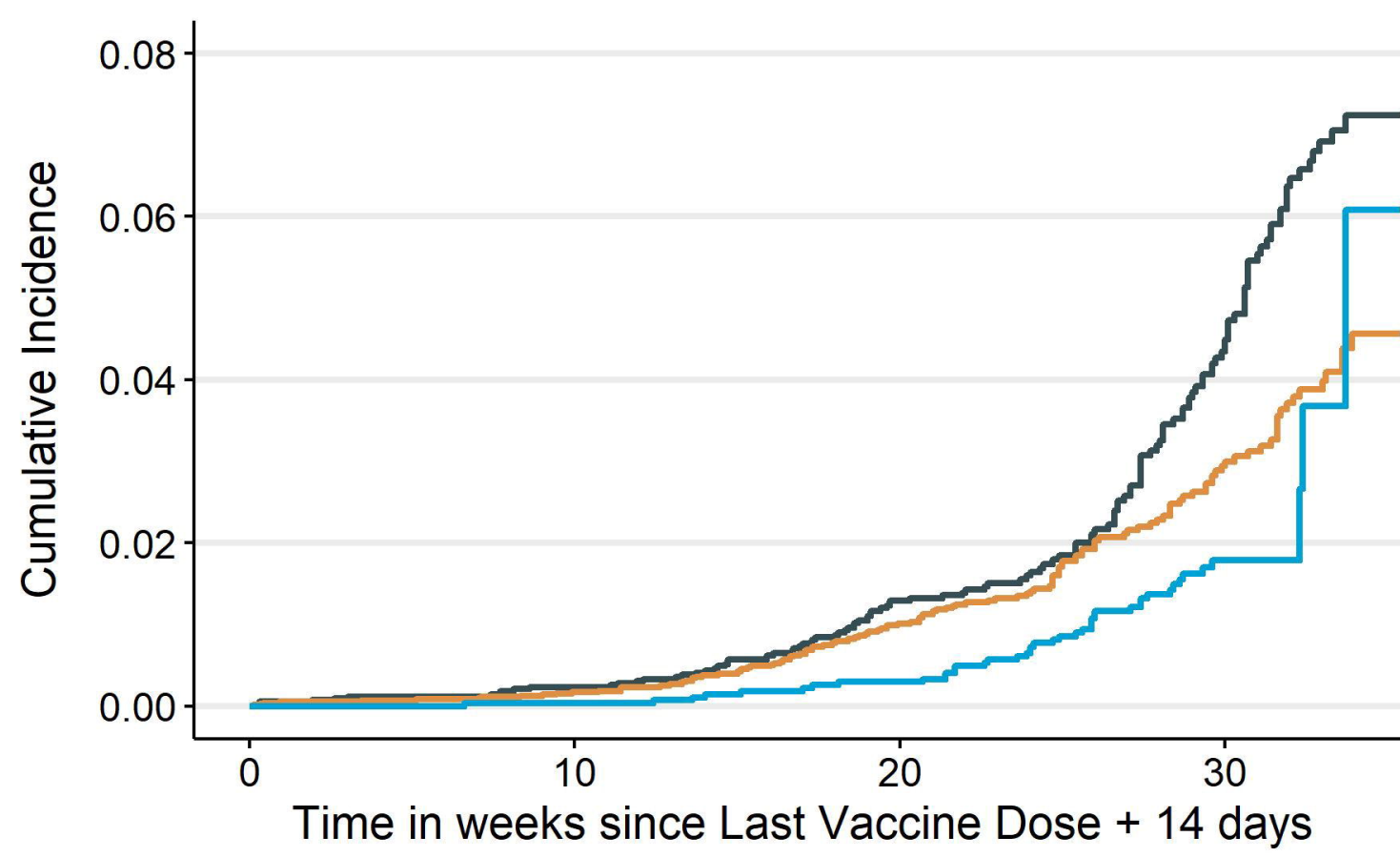

No. at Risk

$\begin{array}{rrrrr}18-44 & 5250 & 4141 & 3176 & 1292 \\ 45-64 & 7585 & 6534 & 5380 & 1743 \\ 65+3185 & 2832 & 2605 & 870\end{array}$

